\title{
Malignant Pineal Region Neoplasm
}

National Cancer Institute

\section{Source}

National Cancer Institute. Malignant Pineal Region Neoplasm. NCI Thesaurus. Code C3573.

Abnormal malignant growth of the cells that comprise the pineal parenchyma. 